https://doi.org/10.18778/7525-969-8.29

Jędrzej Paszkiewicz

\title{
Współpraca regionalna na Bałkanach Zachodnich z perspektywy Unii Europejskiej. Przesłanki i przeszkody
}

Rozwijająca się od zakończenia wojen jugosłowiańskich w drugiej połowie lat 90. XX w. współpraca wielostronna między państwami Europy Południowo-Wschodniej, jest wspierana przez Unię Europejską (UE) jako ważny czynnik mający wspierać proces pokojowej stabilizacji całego regionu. Współpraca regionalna traktowana jest przez Wspólnotę jako integralny element starań wszystkich tamtejszych państw o integrację ze strukturami europejskimi. Połączenie zagadnienia stabilizacji regionalnej z kwestią przygotowania poszczególnych krajów do członkostwa w Unii zostało uwidocznione tuż po zakończeniu działań wojennych w Chorwacji oraz Bośni i Hercegowinie. W dokumentach unijnych pojawił się wówczas aktualny do dzisiaj termin Bałkany Zachodnie. Pojęcie to dotyczy państw aspirujących do Wspólnoty, w większości z obszaru postjugosłowiańskiego, które borykają się ze zbliżonymi przeciwnościami społeczno-politycznymi i ekonomicznymi. Problemy te związane są z trwająca od drugiej połowy lat 90 . XX w. transformacją systemowa, niedostateczną demokratyzacja, zacofaniem ekonomicznym, a także nadal nierozwiązanymi kwestiami dotyczącymi minionych konfliktów zbrojnych ${ }^{1}$.

Od końca lat 90. Unia Europejska działa na rzecz skłonienia poszczególnych państw bałkańskich starających się o członkostwo, by przed akcesją aktywnie współtworzyły system równorzędnych, pokojowych powiązań polityczno-ekonomicznych stabilizujacych stosunki w całym regionie. U podstaw tej strategii leży troska o poprawę stanu bezpieczeństwa ogólnoeuropejskiego, zwłaszcza o zapobieżenie importowi problemów towarzyszaccych relacjom w tzw. postjugosłowiańskiej

${ }^{1}$ Zgodnie z terminologia przyjętą przez instytucje Unii Europejskiej za Bałkany Zachodnie uważa się następujące państwa: Albanię, Bośnię i Hercegowinę (BiH), Chorwację, Czarnogórę, Kosowo, Macedonię i Serbię. Z kolei do Europy Południowo-Wschodniej (w niektórych dokumentach określanej także mianem Bałkanów) zalicza się, obok państw z Bałkanów Zachodnich, Bułgarię, Grecję, Rumunię i Turcję. M. Delević, Regional cooperation in the Western Balkans, „Chaillot Paper”, no. 104, Paris 2007, s. 13-15. 
części Bałkanów do UE². Analizując atmosferę charakteryzującą stytuację polityczną na gruncie postjugosłowiańskim w drugiej połowie lat 90 . XX w. należy podkreślić, że nie sprzyjała ona powstaniu trwalszych form współpracy między państwami, mogącej przełamać dominujace wówczas poczucie zagrożenia. Destabilizacja międzynarodowa w regionie fatalnie rzutowała na stan bezpieczeństwa poszczególnych państw. Niezałatwione spory terytorialne wpływały na to, że działania polityczne poszczególnych rządów były podporządkowane działaniom o charakterze partykularnym, nastawionym na tworzenie przeciwwagi wobec aspiracji wyrażanych przez kraje sąsiednie. Choć w drugiej połowie dekady ton stosunkom na Bałkanach Zachodnich zaczęły stopniowo nadawać dwustronne negocjacje w sprawie porozumień o przyjaźni, w wielu przypadkach nie wspomagały one rozwoju równorzędnej współpracy międzynarodowej w regionie, ponieważ były wymuszone przez mocarstwa, które dążyły do stworzenia trwalszych struktur polityczno-ekonomicznych mających objąć swoim zasięgiem cała skonfliktowaną strefę ${ }^{3}$. Z drugiej strony obranie przez elity polityczne z Bałkanów Zachodnich kierunku euroatlantyckiego w polityce zagranicznej stanowiło jednak punkt wyjścia do popierania poszczególnych inicjatyw wielostronnych. Działania te pozwalają poszczególnym państwom na przejęcie większej odpowiedzialności za stabilizację w regionie i ściślej je wiążą z problematyką bezpieczeństwa ogólnoeuropejskiego.

W stosunkach między Unią Europejską a krajami bałkańskimi aspekt bezpieczeństwa międzynarodowego został integralnie powiązany właśnie z zagadnieniem współpracy wielostronnej, która w intencji jej twórców ma prowadzić również do zrównoważonego rozwoju społeczno-politycznego i ekonomicznego państw regionu. Idea ta znalazła wsparcie w postaci sformułowanego przez Wspólnotę Europejską w czerwcu 1999 r. Paktu Stabilności dla Europy Południowo-Wschodniej (Stability Pact for South Eastern Europe) 4 . Zobowiązywano w nim państwa z obszaru postjugosłowiańskiego, a także Albanię, które aspiruja do członkostwa w Unii, do nawiązania i aktywnego rozwijania współpracy regionalnej mającej pomóc w rozwiązaniu na etapie przedakcesyjnym podstawowych problemów w relacjach wewnątrzbałkańskich ${ }^{5}$. Pierwotnie realizacja Paktu Stabilności została oparta na czterech stworzonych wcześniej inicjatywach wielostronnych, obejmujących Europe Południowo-Wschodnią. Znajduje się

${ }^{2}$ S. Knezović, Poskonfliktni okviri regionalne sigurnosti i suradnje u jugoistočnoj Europi - inicjative Europske Unije, „Politička misao” 2006, vol. 43, br. 2, s. 80.

${ }^{3}$ D. Kostovicova, Slabost države na Zapadnom Balkanu kao pretnja bezbednosti: pristup Evropske Unije i perspektiva globalne politike, „Bezbednost Zapadnog Balkana” 2007-2008, br. 7-8, s. 14.

${ }^{4}$ E. Busek, B. Kühne, From stabilisation to integration. The Stability pact for South Eastern Europe, Wien 2010, s. 11-23.

${ }^{5}$ M. Delević, dz. cyt., s. 23-25. 
wśród nich skonkretyzowany w 1996 r. Proces Współpracy Europy Południowo-Wschodniej (South-East Europe Cooperation Process, SEECP), odnoszący się do tak szeroko nakreślonych dziedzin współpracy, jak bezpieczeństwo, dialog polityczny, intensyfikacja obrotu gospodarczego, rozwój demokracji, praworządność, budowa kapitału ludzkiego i walka ze zorganizowana przestępczością ${ }^{6}$. Z kolei Porozumienie o Strefie Wolnego Handlu w Europie Środkowej (Central European Free Trade Agreement, CEFTA), powołane w 1992 r., a odnowione w 2006 r., zastapiło skomplikowany system 32 dwustronnych porozumień między krajami Europy Południowo-Wschodniej ${ }^{7}$. Kolejnymi ważnymi forami wspomagajacymi rozwój współpracy wielostronnej na Bałkanach są Inicjatywa Środkowoeuropejska (Central European Initiative, CEI) z 1989 r. i Inicjatywa Adriatycko-Jońska (Adriatic Ionian Initiative, AII) z 2000 r., powołane przy wydatnym udziale włoskiej dyplomacji. Początkowo miały one służyć konsultacjom w sprawach polityki międzynarodowej, z czasem objęły współpracę dotyczącą granic, wymiany kulturalno-naukowej i ekologii ${ }^{8}$.

${ }^{6}$ Do SEECP przystapiły: Albania, BiH, Bułgaria, Chorwacja, Grecja, Macedonia, Rumunia, ówczesna Federacyjna Republika Jugosławii (obecnie odrębne państwa Serbia i Czarnogóra), Turcja, a także Mołdawia na prawach obserwatora. Coroczne spotkania na szczycie są zwoływane przez szefa rządu lub głowę państwa, który akurat pełni funkcję koordynatora. Częstsze spotkania konsultacyjne odbywają się na poziomie ministrów spraw zagranicznych i przedstawicieli pozostałych resortów. Nad przygotowaniem i realizacją postanowień szczytów SEECP czuwa specjalny organ, celem sprawniejszego aranżowania wspólnych działań powołano także tzw. Trójkę. W jej ramach działają przedstawiciele SEECP, Komisji Europejskiej i Paktu Stabilizacji (obecnie Rady Współpracy Regionalnej). Tamíe, s. 18.

7 Pierwotnie sygnatariuszami porozumienia były Czechosłowacja, Polska i Węgry, które pozostawały w nim do $2004 \mathrm{r}$. Potem do CEFTA przystapiły w $1996 \mathrm{r}$. Słowenia (do 2004 r.), w 1997 r. Rumunia (do 2007 r.), w 1999 r. Bułgaria (do 2007 r.), w 2003 r. Chorwacja, w 2006 r. Macedonia, w 2007 r. Albania, BiH, Mołdawia, Czarnogóra, Serbia i Kosowo, reprezentowane przez Misję Tymczasowej Administracji Organizacji Narodów Zjednoczonych w Kosowie (UNMIK). Poszczególne państwa występowały z układu po przystapieniu do Unii Europejskiej. Jedynym organem CEFTA jest Komitet Współpracy grupujący ministrów zajmujących się sprawami będącymi w zasięgu działań porozumienia. Szefowie państw członkowskich spotykają się raz w roku. E. Busek, B. Kühne, dz. cyt., s. 191-233.

8 Inicjatywa Środkowoeuropejska działa pod obecną nazwą od 1992 r. Jej poprzedniczkami były inicjatywy o nazwach Quadragonale (1989 r.), Pentagonale (1990 r.) i Hexagonale (1991 r.). W pracach CEI uczestniczą Albania, Austria, Białoruś, BiH, Bułgaria, Chorwacja, Czarnogóra, Czechy, Macedonia, Mołdawia, Polska, Rumunia, Serbia, Słowacja, Słowenia, Ukraina, Węgry i Włochy (10 państw członkowskich UE i 8 krajów spoza Wspólnoty). Głównymi organami CEI są coroczne spotkania szefów rządów i spotkania ministrów spraw zagranicznych. Stały Sekretariat Wykonawczy CEI znajduje się w Trieście. CEI współfinansuje trzy tzw. fundusze wspierające wykorzystywane do rozwijania projektów finansowanych z wielu źródeł. M. Delević, dz. cyt., s. 21-22; D. Kekić, Jadransko-jonska inicijativa, „Međunarodni problemi” 2004, vol. 55, br. 3-4, s. 413-433. 
U podstaw Paktu Stabilności stała konieczność wypracowania takich mechanizmów współpracy międzypaństwowej, które sprzyjałyby rozwojowi gospodarczemu i wzmocnieniu mechanizmów demokratycznych we wszystkich państwach regionu. Twórcy Paktu starali się kompleksowo podejść do sytuacji na Bałkanach uznając, że pod koniec lat 90 . nadal była ona determinowana przez czynniki prowadzące do dalszej dezintegracji stosunków społeczno-politycznych i ekonomicznych. Oprócz państw z Bałkanów Zachodnich Pakt obją początkowo także Rumunię, Bułgarię i Mołdowę . W jego ramach powołano trzy Grupy Robocze (working tables), których celem było wspomaganie i ocena działań podejmowanych przez poszczególne państwa w różnych dziedzinach życia społeczno-ekonomicznego. Pierwsza grupa zajmowała się kwestiami demokratyzacji i praw człowieka, druga współpracą prawno-ekonomiczna, rozwojem gospodarczym i odbudową ze zniszczeń wojennych. Trzecie gremium pracowało nad zagadnieniami dotyczącymi bezpieczeństwa. Pakt stabilizacyjny po raz pierwszy miał zgromadzić przy jednym stole na równych prawach wszystkich partnerów procesu: państwa Bałkanów Zachodnich i spoza regionu (Szwajcaria, Kanada, Japonia, Norwegia, Rosja, USA), państwa członkowskie Unii Europejskiej, a także najważniejsze międzynarodowe organizacje i instytucje finansowe. Podstawową formą działalności były organizowane cyklicznie konferencje poświęcone istotnym dla współpracy regionalnej kwestiom ${ }^{10}$.

Proces aranżowany przez Unię Europejską na podstawie Paktu Stabilności miał na celu odtworzenie więzi między sąsiadującymi państwami i narodami, przywrócenie wspólnego dziedzictwa historycznego i kulturowego regionu, który w okresie zdominowanym przez partykularyzmy etniczno-religijne został poważnie osłabiony. Bez watpienia rozwojowi więzi regionalnych, wspieranemu przez UE, służyło poparcie większości społeczeństw z Bałkanów Zachodnich dla integracji europejskiej. Jednocześnie stanowisko Wspólnoty w sprawie form współpracy regionalnej było często krytykowane przez rządy poszczególnych państw, które uznawały je za arbitralne, nie liczące się ze skomplikowaną rzeczywistością polityczno-kulturową regionu. Krytycy Paktu wytykali, że często zmuszał on władze do działań „na pokaz”, obliczonych na uzyskanie pozytywnej oceny od Komisji Europejskiej, a niekorzystnych dla interesów narodowych. W rezultacie nie rozwiązywał rzeczywistych problemów w stosunkach międzypaństwowych,

9 Jako państwa wspierające udział wzięły kraje członkowskie UE, Komisja Europejska, Szwajcaria, Norwegia, Rosja, Stany Zjednoczone, Japonia, jako obserwator Ukraina, a także wiele organizacji międzynarodowych (m.in. NATO, ONZ, OBWE, UNHCR, Rada Europy, Bank Światowy i Międzynarodowy Fundusz Walutowy). S. Knezović, dz. cyt., s. 105.

${ }_{10} \mathrm{Z}$ procesem stabilizacji i stowarzyszenia, realizowanym na podstawie Paktu Stabilności powiązano wszystkie umowy o stowarzyszeniu między państwami z Bałkanów Zachodnich a UE z lat 2001-2008. Dokumentacja pracy regionalnych grup roboczych z lat 1999-2008: E. Busek, B. Kühne, dz. cyt., passim. 
ale sprzyjał nasileniu rywalizacji między poszczególnymi państwami, aspirującymi do członkostwa w strukturach euroatlantyckich ${ }^{11}$.

W trakcie ponad dwudziestoletniego okresu działań związanych z aranżowaniem systemu współpracy regionalnej na Bałkanach Zachodnich, w największym stopniu zaistniała ona w sektorze transportowym, energetycznym, w poszczególnych dziedzinach polityki społeczno-ekonomicznej oraz we współpracy policyjnej. Większość inicjatyw powstała na podstawie Paktu Stabilizacji i niezmiennie wpisuje się w system powiązań polityczno-ekonomicznych w całej Europie Południowo-Wschodniej. I tak w 2001 r. państwa regionu przyjęły pakt intencyjny o rozwoju regionalnej sieci transportowej (Memorandum of Understanding on the Development of the SEE Core Regional Transport Network). $\mathrm{W}$ jego ramach przewidziano ułatwienia celne i realizację projektów infrastrukturalnych zakładających stworzenie jednolitego systemu komunikacyjnego w regionie. Pod auspicjami Unii Europejskiej stworzony został także zarys zintegrowanej sieci transportowej, lądowej i rzecznej obejmującej państwa postjugosłowiańskie oraz Albanię (SEE Core Regional Transport Network) ${ }^{12}$. W 2002 r. na podstawie paktu stabilizacyjnego sformułowano również cele Danube Cooperation Process (DCP), dotyczące ujednolicenia zasad żeglugi dunajskiej, i International Sava Basin Commission, której zadaniem jest zrównoważone gospodarowanie zasobami naturalnymi w dorzeczu rzeki Sawy ${ }^{13}$. Z kolei współpraca w dziedzinie energetycznej została oparta na tzw. Energy Community Treaty, zawartym między Unią a państwami bałkańskimi, który wszedł w życie w 2006 r. Stworzył on podstawy prawne pod działania w kierunku integracji poszczególnych rynków energetycznych i ujednolicenia zasad eksploatacji gazu ziemnego ${ }^{14}$. Odrębną kategorię współpracy stanowią działania dotyczące wspierania reform ekonomicznych, związane z wyspecjalizowaną instytucją o charakterze eksperckim o nazwie Investment Compact for South East Europe. Działa ona pod kuratela Organizacji Współpracy Gospodarczej i Rozwoju (OECD) oraz Komisji Europejskiej. Udziela poszczególnym rządom wsparcia merytorycznego dla projektów reform gospodarczych, a także ocenia ich realizację ${ }^{15}$. Podobną rolę

${ }_{11}$ Por. S. Knezović, dz. cyt., s. 97.

${ }^{12}$ E. Busek, B. Kühne, dz. cyt., s. 255-272; por. N. Nikolic, SEE Core Regional Transport Network Development, South-East Europe transport observatory, 2010 http:// www.seetac.eu/media/9930/see\%20core\%20regional\%20transport\%20network\%20development.pdf (dostęp 12 VI 2012).

${ }^{13}$ E. Busek, B. Kühne, dz. cyt., s. 273-296; S. Mameli, Regional cooperation in Western Balkans in times of political and economical uncertainty, „PECOB's Papers Series”, 2011, no. 8, s. 10-11.

${ }^{14}$ www.eur-lex.europa.eu/LexUriServ/LexUriServ.do?uri=OJ:L:2006:198:0018:001 8:EN:PDF (dostęp 12 VI 2012).

15 E. Busek, B. Kühne, dz. cyt., s. 237-242; por. http://www.investmentcompact.org (dostęp 12 VI 2012). 
w zakresie polityki społecznej odgrywa tzw. proces bukareszteński (Bucharest Employment Process), zainicjowany w październiku 2003 r. ${ }^{16} \mathrm{Z}$ kolei celem Elektronicznej Inicjatywy Europy Południowo-Wschodniej (Electronic South Eastern Europe Initiative, ESEE), działajacej od stycznia 2001 r., jest pomoc we wdrażaniu nowoczesnych technologii komunikacyjnych w administracji rządowej, instytucjach gospodarczych i szkołach ${ }^{17}$.

Ważne elementy współpracy regionalnej na forum bałkańskim stanowia bezpieczeństwo granic i walka ze zorganizowana przestępczością. W tej dziedzinie państwa regionu współdziałają od roku 1999 w ramach Regionalnego Centrum do Spraw Walki z Przestępczością Transgraniczną (Regional Centre for Combating Trans-border Crime), które jest nadzorowane przez Regionalne Centrum Inicjatywy Współpracy Europy Południowo-Wschodniej (SECI) ${ }^{18}$. Walce z korupcją poświęcono zawarty w 2000 r. Stability Pact Anticorruption Initiative (SPAI). W szczególności ma ona wspomagać reformę służb policyjnych i wspierać działania antykorupcyjne na różnych szczeblach w państwach regionu. W ramach współpracy dotyczacej kontroli nad transportem broni w 2000 r. powołane zostało centrum weryfikacji broni (Regional Arms Control Verification and Implementation Center, RACVIAC). Jest ono wspomagane przez stworzoną dwa lata później agendę zbierającą informacje o wykorzystaniu tzw. lekkiej broni palnej (South-Eastern and Eastern Europe Clearinghouse for the Control, of Small Arms and Light Weapons, SEESAC) ${ }^{19}$. Z kolei przyjęta w 2004 r. Migration, Asylum, Refugees Regional Initiative (MARRI) ma umożliwić stworzenie systemu zintegrowanej kontroli ruchu granicznego w regionie. W 2006 r. państwa bałkań-

${ }^{16}$ E. Busek, B. Kühne, dz. cyt., s. 383-389. Spośród inicjatyw podjętych w okresie obowiązywania Paktu Stabilności, obejmujących państwa z Bałkanów Zachodnich, warto wymienić np. inicjatywę skierowaną na wzmacnianie szans politycznych i zawodowych kobiet (Gender Task Force, od 1999), i na wyrównywanie poziomu edukacji w poszczególnych państwach (Education Reform Initiative of South Eastern Europe, ERI SEE, od 2004 r.). Inna inicjatywa dotyczyła harmonizacji rynków zatrudnienia (Centre of Public Employment Services of South East European countries, CPESSEC, od 2007 r.). W tym samym czasie realizowano dwa programy dotyczące współpracy między rynkami pracy państw położonych nad Adriatykiem (SVILMA, 2004-2006, DILMA 2007-2009). Z kolei w latach 2008-2010 rozwijano program pod auspicjami Komisji Europejskiej i Rady Europy promujacy reformy systemu ochrony socjalnej we wszystkich państwach regionu. H. Vidovic, V. Gligorov, R. Haupfleisch, M. Holzner, K. Korolkova, M. Natter, Developing efficient activation approaches and identifying elements for regional cooperation in the Western Balkans, „Research Reports”, 2011, no. 374, s. 146-147.

17 E. Busek, B. Kühne, dz. cyt., s. 296.

18 Regionalne Centrum Inicjatywy Współpracy Europy Południowo-Wschodniej (Southeast European Cooperative Initiative Regional Center) powstało w 1996 r. jako forum współpracy międzynarodowej w walce z przestępczościa. Akt fundacyjny SECI: tamże, s. $28-31$.

19 Tamże, s. 199-203; M. Delević, dz. cyt., s. 60-93. 
skie podpisały natomiast konwencję o współpracy policyjnej (Police Cooperation Convention for South East Europe), której dalekosiężnym celem jest ujednolicenie zasad kontroli granicznej i stworzenie systemu poszukiwania osób i przedmiotów, wzorowanego na Systemie Informacyjnym Schengen (SIS) ${ }^{20}$.

Omówione powyżej przedsięwzięcia odnoszą się do konkretnych dziedzin aktywności. Mają się one składać na ogólniejszą współpracę o wymiarze ogólnoregionalnym, a także wpisuja się w istniejące już zasady współdziałania w ramach Unii Europejskiej. Wszystkie rozwijają się z udziałem poszczególnych instytucji Wspólnoty korzystając z ich wsparcia merytorycznego, logistycznego i finansowego.

W celu usprawnienia przepływu informacji i funduszy między organizacjami międzynarodowymi a państwami bałkańskimi, w 2007 r. Pakt Stabilności został zastapiony przez Radę Współpracy Regionalnej (Regional Cooperation Council $)^{21}$. Jej głównym celem jest wspieranie i koordynacja najważniejszych nurtów współpracy regionalnej w Europie Południowo-Wschodniej w celu ich konsolidacji. Za priorytetowe twórcy Rady uznali pięć obszarów działalności odpowiadających dziedzinom wcześniej wyodrębnionym przez Pakt Stabilności. Sa to rozwój gospodarczy i społeczny, infrastruktura i energia, wymiar sprawiedliwości i sprawy wewnętrzne, współpraca w dziedzinie bezpieczeństwa oraz doskonalenie jakości kapitału ludzkiego. Zadaniem Rady jest wspieranie postępu we wszystkich tych obszarach, a także nadanie współpracy regionalnej w miarę jednolitych ram organizacyjnych. Instytucja ta ma również być czymś w rodzaju „operacyjnej odnogi” politycznego procesu współpracy (SEECP), rozwijanego od 1996 r. przez państwa regionu. Jej zadaniem jest pośrednictwo w wymianie informacji między państwami regionu a organizacjami finansowymi i pomoc w konkretyzowaniu projektów o współpracy ponadpaństwowej22.

${ }^{20}$ E. Busek, B. Kühne, dz. cyt., s. 108.

${ }^{21}$ Rada Współpracy Regionalnej rozpoczęła działalność w lutym 2008 r. w Sarajewie. Pierwszym sekretarzem generalnym został Hido Biščević, sekretarz stanu w Ministerstwie Spraw Zagranicznych i Europejskiej Integracji w rządzie Chorwacji. Do Rady należy 46 państw, w tym wszystkie kraje z Bałkanów Zachodnich. W jej pracach uczestniczą także przedstawiciele Unii Europejskiej, SEECP, Rady Europy, Europejskiego Banku Odbudowy i Rozwoju (EBOiR), Europejskiego Banku Inwestycyjnego (EBI), NATO, Organizacji Współpracy Gospodarczej i Rozwoju (OECD), Organizacji Bezpieczeństwa i Współpracy w Europie (OBWE), Banku Światowego i dwóch agend ONZ - Programu ds. Rozwoju oraz Europejskiej Komisji Gospodarczej. UE jest w Radzie reprezentowana przez Komisję Europejska, Prezydencję i Sekretariat Rady Europejskiej. Budżet na roczną działalność Rady Współpracy Regionalnej opiewa na około $3 \mathrm{mln}$ euro. Po milionie euro dokładają UE, organizacje międzynarodowe wraz z państwami spoza regionu zasiadającymi w Radzie (Kanada, Norwegia, Szwajcaria, USA) oraz państwa regionu. Statut Rady: tamże, s. 680-686.

${ }^{22} \mathrm{~W}$ ciąu dwóch lat działalności Rady pod jej auspicjami stworzono grupy robocze pracujące m.in. nad wymianą edukacyjno-badawczą (Task Force Fostering and Building Human Capital, TF FBHC, od czerwca 2008 r.), współpracą w dziedzinie zatrudnienia 
W intencji Unii Europejskiej Rada Współpracy Regionalnej ma do odegrania zasadniczą rolę w tworzeniu przestrzeni współpracy o charakterze ponadpaństwowym, która umożliwiłaby osłabienie wpływu barier będących spadkiem po wojnach jugosłowiańskich na całokształt odniesień bałkańskich. Działalność Rady jest także istotna dla krajów regionu, ponieważ do jej kompetencji należy wykorzystanie funduszy kierowanych na projekty o charakterze wielostronnym, przewidzianych chociażby w puli Multi-Beneficiary Instrument for Pre-Accession Assistance (MB-IPA), który jest realizowany od początku 2010 r. ${ }^{23}$

Intencją Unii Europejskiej było stworzenie instytucji łączącej unijne działania polityczno-ekonomiczne, wspierające ideę współpracy regionalnej, z aktywnością poszczególnych państw zaangażowanych w ten proces. Komisja Europejska podkreśla, że Rada jest preferowanym przez nią forum, na którym powinna rozwijać się i integrować współpraca zainicjowana przez Pakt Stabilizacji2 ${ }^{24}$ W Brukseli ocenia się bowiem, że proces współpracy regionalnej na Bałkanach Zachodnich do tej pory rozwija się nierównomiernie i w zbyt dużym rozproszeniu. Typową cechą poszczególnych inicjatyw politycznych jest stosunkowo niski stopień instytucjonalizacji oraz ich fragmentaryczność. Charakterystyczne jest również to, że wiele spraw dotyczących całych Bałkanów Zachodnich albo pozostaje domeną stosunków dwustronnych, albo poruszanych jest na marginesie problemów dyskutowanych na forum skupiającym państwa z Europy Południowo-Wschodniej i Środkowowschodniej. Rządy republik postjugosłowiańskich nie wyrażają większego zainteresowana współpracą o węższym zasięgu, obejmującą wyłącznie region Bałkanów Zachodnich, gdyż są zaangażowane w spory o rozliczenia polityczne i finansowe minionych konfliktów zbrojnych oraz realizuja rozbieżne interesy narodowe. Wiele spornych spraw

i polityki społecznej (Employment and Social Policy Network Fostering and Building Human; ESPN, od 2009 r.), wsparciem edukacyjnym dla przedsiębiorców (South East European Centre for Entrepreneural Learning; SEE CEL, od października 2008 r.); H. Vidovic [i in.], dz. cyt., s. 146-147.

${ }^{23}$ IPA. Multi-annual indicative planning document 2011-2013, s. 10, www.ec.europa.eu/enlargement/pdf/mipd_multibeneficiary_2011_2013_en.pdf (dostęp 11 VI 2012). W grudniu 2009 r. powołano do życia także inwestycyjny program ramowy dla Bałkanów Zachodnich (The Western Balkans Investment Framework, WBIF), którego wartość ustalono na $180 \mathrm{mln}$ euro. Zaangażowanie finansowe UE sięga $130 \mathrm{mln}$ euro. EBI, EBOiR i Bank Rozwoju Rady Europy (CEB) wsparły program 30 mln euro, a państwa regionu mają wyasygnować ogółem $20 \mathrm{mln}$ euro. Wsparcie finansowe dotyczy zwłaszcza sektora energetycznego i transportowego, a także polityki społecznej, ekologii i rozwoju sektora prywatnego; por. http://www.wbif.eu (dostęp 12 VI 2012).

${ }^{24}$ Komunikat Komisji Europejskiej do Parlamentu Europejskiego i Rady. Strategia rozszerzenia i najważniejsze wyzwania na lata 2011-2012, Bruksela 2011, s. 8, http:// ec.europa.eu/enlargement/pdf/key_documents/2011/package/strategy_paper_2011_pl.pdf (dostęp 12 VI 2012). 
wyłączono z wielostronnego dyskursu także z powodu braku politycznej odwagi ze strony polityków. Istnieje wśród nich przekonanie, że wyniesienie niektórych kwestii na forum współpracy wielostronnej zostałoby bardzo źle odebrane przez poszczególne społeczeństwa. Te nie dają legitymacji liderom państwowym, by podejmowali rzeczową dyskusję o bolesnych rozrachunkach z przeszłości ${ }^{25}$.

W polityce bałkańskiej przewagę zyskał pogląd, że najbardziej bolesne, „czułe” dla stosunków wzajemnych, rozbieżności powinny być rozstrzygane bezpośrednio przez zainteresowane strony tak, by nie zaburzyć z trudem rozwijanego procesu stabilizowania sytuacji politycznej w regionie. Podejście to utrudnia tworzenie projektów nastawionych na dialog w takich sprawach, jak chociażby edukacja historyczna. Kwestia, która mogłaby stać się elementem ściślejszej współpracy jest ściganie podejrzanych lub oskarżonych o zbrodnie popełnione podczas konfliktów jugosłowiańskich w latach 90 . XX w. Problem ten ma zasięg ogólnoregionalny, bo sprawcy, ofiary, świadkowie mieszkają w różnych państwach. Zacieśnienie systemu współpracy między organami ścigania mogłoby znaczacco przyspieszyć proces rozliczeń z okresem wojen, a przy okazji umożliwić lepszą koordynację działań na rzecz walki ze zorganizowaną przestępczościa. Tymczasem do 2011 r. zdołano podpisać zaledwie kilka dwustronnych układów o deportacji osób podejrzanych o przestępstwa kryminalne i zbrodnie wojenne ${ }^{26}$. Ściślejsza współpraca między państwami z Bałkanów Zachodnich umożliwiłaby także dojście do ładu z wieloma problemami dotyczącymi uchodźców (lub tzw. displaced persons), ze szczególnym uwzględnieniem działań zmierzających do stworzenia możliwości powrotu ludności wypędzonej w trakcie wojen. Regionalną deklarację w tej kwestii przyjęły w Sarajewie w 2005 r. Bośnia i Hercegowina, Chorwacja, Serbia i Czarnogóra, ale nie poszły za tym żadne poważniejsze przedsięwzięcia ${ }^{27}$. Duża wrażliwość państw i społeczeństw bałkańskich na sporną problematykę etniczno-religijna, a także duża rola polityki historycznej w sferze wewnętrznej oraz zewnętrznej sprawiają że istnieje silny opór przed rozpatrywaniem bolesnych spraw na forum wielostronnym. Kwestie te stanowią poważną

${ }_{25}$ D. Đukanović, Zapadni Balkan: od sukoba do evrointegracija, „Godišnjak Fakulteta političkih nauka. Univerzitet u Beogradu” 2009, vol. 3, br. 3, s. 502-504.

${ }^{26}$ Realne podstawy prawne pod rozwój współpracy regionalnej w sprawach kryminalnych są tworzone dopiero w ostatnich latach poprzez bilateralne umowy o ekstradycji. Już w 2006 r. uczyniły to BiH i Macedonia. Trzy lata później układ o ekstradycji zawarły Serbia i Czarnogóra. W 2010 r. przyjęto umowy BiH-Chorwacja, Serbia-Chorwacja i Czarnogóra-Chorwacja. W 2011 r. dwustronne układy o ekstradycji z Chorwacją i Serbią podpisała Macedonia. W maju 2012 r. pomyślnie zakończyły się rozmowy o umowie ekstradycyjnej między Serbią a BiH, negocjacje w tej sprawie podjęły Serbia i Albania, IPA. Multi-annual..., s. 6.

${ }^{27}$ Declaration of Regional Ministerial Conference on Refugee Returns, 31 I 2005, http://www.unhcr.org/refworld/docid/451a5acc4.html (dostęp 12 VI 2012). 
barierę dla współdziałania ponad granicami. Nie tylko zawężają jego zakres, ale i osłabiają szansę na trwałą zmianę relacji międzynarodowych w regionie ${ }^{28}$.

W rezultacie $\mathrm{w}$ procesie konkretyzowania form współpracy międzynarodowej na Bałkanach Zachodnich zwraca uwage obecność wielu inicjatyw o różnym charakterze i zasięgu, począwszy od forów międzyrządowych i okrągłych stołów, skończywszy zaś na przedsięwzięciach o charakterze oddolnym, nastawionych na integrację wspólnot zamieszkujacych tereny wieloetniczne lub transgraniczne. Ich celem jest zazwyczaj wspieranie tzw. małej integracji dotyczącej poszczególnych sfer życia społeczno-politycznego i ekonomicznego. Uwagę zwraca także stosunkowo duża liczba inicjatyw, których pola działania wzajemnie się nakładaja. Z jednej strony osłabia to efektywność poszczególnych przedsięwzięć, a osoby zajmujące się nimi nierzadko zmuszone są do rywalizacji między sobą o wsparcie finansowe z zewnątrz. Z drugiej strony pewna „demokratyzacja" w zakresie działań dotyczących poszczególnych sfer współpracy może jednak sprzyjać wzmacnianiu dialogu między poszczególnymi stronami. Oczywiście jednolita organizacja o sprecyzowanych kompetencjach, stabilnym finansowaniu i szerokim obszarze oddziaływania mogłaby efektywniej kontrolować cały proces współpracy regionalnej i wszystkie podmioty w niej uczestniczące. W państwach Bałkanów Zachodnich istnieje jednak silna niechęć wobec prób tworzenia ponadnarodowego gremium, które przywołują przykre doświadczenia z czasów komunistycznej federacji jugosłowiańskiej. Ponieważ dążenia do politycznej reintegracji państw regionu jako całości są w zasadzie odrzucane przez wszystkich uczestników tamtejszej polityki, instytucjonalne i merytoryczne „rozbicie” współpracy regionalnej można traktować jako sprzyjające pluralizacji stosunków i umacnianiu partnerstwa we wzajemnych relacjach ${ }^{29}$.

Wielu obserwatorów stosunków bałkańskich uważa, że proces współpracy polityczno-ekonomicznej na Bałkanach Zachodnich nie jest na razie w stanie zmienić miejscowych stosunków opartych na tradycyjnej nieufności, a nawet wrogości między poszczególnymi społeczeństwami. Z punktu widzenia państw regionu najważniejszym celem politycznym jest maksymalne zbliżenie się do oczekiwań Wspólnoty Europejskiej przy możliwie jak najmniejszym zaangażowaniu w proces współpracy z sąsiadami. W całokształcie polityki zagranicznej państw bałkańskich współdziałanie z innymi krajami regionu pozostaje zwykle na drugim planie. W większości przypadków brakuje woli zaangażowania się elit politycznych w żmudny i kontrowersyjny społecznie proces rozwiązywania nabrzmiałych problemów etnicznych, co w przypadku Serbii i Chorwacji musiałoby oznaczać np. definitywne odejście od wspierania irredentyzmów w Bośni i Hercegowinie, znajdującej się na skraju rozpadu z powodu różnic narodowych. Z pewnością brakuje także odpowiednio silnych bodźców sprzyjających konkretyzowaniu wspólnego stanowiska państw bałkańskich wobec spraw

${ }^{28}$ R. Belloni, European integration and the Western Balkans: lessons, prospects and obstacles, „Journal of Balkan and Near Eastern Studies” 2009, vol. 11, no. 3, s. 62.

${ }^{29}$ S. Knezović, $d z$. cyt., s. 94. 
zewnętrznych, w tym także wobec działań Wspólnoty Europejskiej. U podstaw negatywnego nastawienia do prób zacieśnienia współpracy regionalnej poza zasięgiem Unii leży strach, że we wzajemnych relacjach odżyja tendencje hegemoniczne, a także przekonanie, że w sprawie członkostwa we Wspólnocie każde państwo powinno działać na własny rachunek, bez oglądania się na interesy sasiadów ${ }^{30}$. Pewne przesłanki świadcza, że współpracy wielostronnej nie sprzyja także swego rodzaju rywalizacja między państwami bałkańskimi aspirującymi do członkostwa. Wymiana doświadczeń w tym zakresie byłaby korzystna z punktu widzenia atmosfery politycznej, a także koordynacji niektórych działań politycznych. W praktyce proces ten wymagałby, zwłaszcza od państw najbardziej zaawansowanych w działaniach dostosowawczych do wymagań unijnych, udostępnienia bałkańskim partnerom swoich osiagnięć w tym zakresie. Kroki te są utrudnione ze względu na brak równowagi między poszczególnymi krajami w realizacji warunków członkostwa. Chorwacja, która do tej pory spośród państw z Bałkanów Zachodnich poniosła największe koszty w dziele tłumaczenia acquis communautaire i dostosowania swojego systemu prawnego do standardów europejskich, nie jest raczej skłonna dzielić się wiedzą na ten temat z sąsiadami ${ }^{31}$.

Połaczenie w strategii UE wobec Bałkanów Zachodnich zagadnienia członkostwa we Wspólnocie z kwestią stabilizacji i współpracy regionalnej sprawiło, że wśród miejscowych społeczeństw nadal utrzymuje się niepewność co do perspektywy integracji europejskiej. Jeszcze w latach 90. zastanawiano się na Bałkanach na ile członkostwo w Unii Europejskiej było celem realnym, a na ile mirażem politycznym majacym studzić wojownicze nastroje polityczne w regionie. Obawy, że Wspólnota będzie dążyć do korekty swojej strategii wobec państw regionu, uznając działania na rzecz współpracy regionalnej za zastępujące proces rozszerzenia, były akcentowane w latach 2008-2009 w związku z działalnościa Rady Współpracy Regionalnej. Wydaje się, że w stolicach bałkańskich poważnie brano wówczas pod uwagę możliwość zwrócenia się Unii Europejskiej ku koncepcji zakładającej spowolnienie procesu rozszerzenia aż do momentu rozstrzygnięcia przez nie dwustronnych kontrowersji politycznych. Przedstawiciele poszczególnych rządów podkreślali, że w staraniach o członkostwo we Wspólnocie w największym stopniu powinny być brane pod uwagę indywidualne starania kandydatów, a dopiero w drugiej kolejności zgodne współdziałanie w ramach szerokiej struktury regionalnej, skupiającej kraje znajdujące się na różnych etapach drogi do integracji europejskiej ${ }^{32}$.

${ }^{30}$ V. Gligorov, Southeast Europe: regional cooperation with multiple equilibria, [w:] Integrating the Balkans in the European Union: functional borders and sustainable security, „IBEU Research Project. Working Paper”, 2004, no. 4.1, s. 2.

${ }^{31}$ S. Mameli, $d z$. cyt., s. 9.

32 SEE region should continue to be priority of EU presidencies, „Macedonian Diplomatic Bulletin” 2008, no. 17, s. 3; R. Manchin, Balkan public opinion and EU accession, [w:] The Western Balkans and the EU: the 'Hour of Europe', ed. by J. Rupnik, „Chaillot Papers", no. 126, Paris 2011, s. 163-166. 
Rozwój współpracy wielostronnej na Bałkanach pod kuratelą Rady Współpracy Regionalnej napotkał poważne problemy także ze względu na kontrowersje dotyczące statusu międzynarodowego Kosowa, które w 2008 r. jednostronnie ogłosiło niepodległość. Między państwami reprezentowanymi w Radzie rozgorzała dyskusja czy Kosowo może być traktowane jako równorzędny beneficjent programów regionalnych wspieranych przez Wspólnotę. Od początku istnienia Rady Kosowo, uznawane przez władze serbskie za „zbuntowana prowincję, jest w niej reprezentowane przez przedstawicieli administracji międzynarodowej (UNMIK) powołanej w 1999 r. przez ONZ na mocy rezolucji nr 1244 Rady Bezpieczeństwa ${ }^{33}$. Autorytet Rady w oczach poszczególnych rządów bałkańskich z pewnością osłabiły również kłopoty z finansowaniem różnych dziedzin współpracy wielostronnej. W następstwie kryzysu ekonomicznego, w latach 2008-2010 Unia Europejska ograniczyła fundusze przeznaczone na wspieranie programów regionalnych, co spotkało się z krytyką na Bałkanach i osłabiło rolę Rady w całokształcie polityki regionalnej ${ }^{34}$. Mimo tych problemów w programie działalności Rady na lata 2011-2014 zapisano, że będzie ona dążyć do przejęcia kluczowej roli względem różnych przejawów współpracy wielostronnej na Bałkanach Zachodnich. W strategii działań na rzecz tworzenia koherentnego systemu współpracy regionalnej należy jednak w znacznie większym stopniu uwzględnić potrzeby regionu opierając się na wnikliwych badaniach i konsultacjach z zainteresowanymi stronami. Ponadto Rada powinna zyskać większą aprobatę ze strony opinii publicznej, dlatego wskazane jest, by wcześniejsze działania polityczne uzupełnić o inicjatywy silniej angażujące miejscowe społeczeństwa. Być może szansą na utwierdzenie międzynarodowej pozycji Rady będzie skoncentrowanie się bardziej na technicznym aspekcie współpracy, rozwijającej się na różnych poziomach życia publicznego, a nie tylko w sferze oficjalnych kontaktów międzyrządowych ${ }^{35}$.

Nie ulega wątpliwości, że warunkiem dynamicznego rozwoju współpracy regionalnej jest uczynienie $\mathrm{z}$ niej priorytetu $\mathrm{w}$ staraniach o integrację państw regionu ze Wspólnotą Europejska. Należy silniej zakorzenić ją w miejscowej praktyce społeczno-politycznej i ekonomicznej, przekonać elity polityczne i społeczeństwo, że jest to perspektywiczny sposób łagodzenia napięć i dochodzenia do konsensusu w najbardziej spornych kwestiach, bez konieczności odwoływania się do sił zewnętrznych. Dopiero wówczas współpraca między państwami z Bałkanów Zachodnich stanie się niezaprzeczalnym elementem stabilizacji poli-

${ }^{33}$ S. Mameli, $d z$. cyt., s. 21-25. UNMIK reprezentuje Kosowo także na innych forach dotyczących współpracy regionalnej w Europie Południowo-Wschodniej.

${ }^{34}$ Regional response to effects of global financial crisis, „Macedonian Diplomatic Bulletin" 2008, no. 20, s. 3.

35 S. Mameli, $d z$. cyt., s. 11-14. 
tycznej, utwierdzi dobre stosunki międzysąsiedzkie i pomoże w przezwyciężeniu nacjonalizmów i nietolerancji ${ }^{36}$.

Na razie, po upływie kilkunastu lat od przyjęcia Paktu Stabilności, trudno oczekiwać, by współpraca wielostronna tworzyła na gruncie bałkańskim jakąś nową jakość polityczną i osłabiała wpływ czynników dezintegracyjnych na stosunki w regionie ${ }^{37}$. Liczba, forma i proces kształtowania postanowień o współpracy regionalnej stanowia jednak bezcenną wartość z punktu widzenia praktyki międzynarodowej. Łączą się one przecież z koniecznością tworzenia kanałów komunikacyjnych, z nieustanną wymianą informacji, a także z prowadzeniem dialogu uwzględniającego interesy wszystkich stron negocjacji. Taka współpraca jest czymś bezprecedensowym w regionie o dziedzictwie komunistycznym, gdzie jeszcze niedawno trwały konflikty zbrojne między sasiadami. Dla państw z Bałkanów Zachodnich z pewnością stanowi ona przedsmak funkcjonowania w ramach Unii Europejskiej, nawet jeśli na drodze do pełnej współpracy nadal stoi wiele niezałatwionych spraw.

${ }^{36}$ S. Knezović, dz. cyt., s. 114.

${ }_{37}$ Por. C. Koneska, Regionalni identitet: faktor Koju nedostaje u saradnji u oblasti bezbednosti na Zapadnom Balkanu, „Bezbednost Zapadnog Balkana” 2007-2008, br. 7-8, s. $117-118$. 